\title{
Development of Science in the Republic of Tatarstan
}

\author{
Ramil R. Khayrutdinov ${ }^{1} \&$ Ildar R. Karimov ${ }^{2}$ \\ ${ }^{1}$ Kazan (Volga Region) Federal University, Kazan, Russia \\ ${ }^{2}$ Institute of Archaeology named after A. Kh. Khalikov of Academy of Sciences of the Republic of Tatarstan, \\ Kazan, Russia \\ Correspondence: Ramil R. Khayrutdinov, Kazan (Volga Region) Federal University, 420008, Kazan, \\ Kremlyovskaya Street, 18, Russia. E-mail: ramilh64@mail.ru
}

Received: June 15, 2015 Accepted: June 24, 2015 Online Published: June 30, 2015

doi:10.5539/jsd.v8n7p99 URL: http://dx.doi.org/10.5539/jsd.v8n7p99

\begin{abstract}
The issue under study is urgent since there is need to give a complex analysis of the development of science in the Republic of Tatarstan and the formation of an integrated understanding of the ways and trends of its development in this large region of Russia. The purpose of the article is to explore the basic components of science policy in the Republic of Tatarstan and to study the structure of the regional scientific capacity in its organizational and personnel aspects. The leading method of the research was a comprehensive approach based on the study of different types of sources. The study analyzed the factors driving the process of regionalization of science and the stages of formation of regional science policy. The formation of mechanism of regional coordination of science and the systems managing a complex of scientific institutions in the Republic of Tatarstan have been studied. The findings of the research may be used in doing general research on the history of science in the Republic of Tatarstan and Russia as a whole, developing special academic courses and teaching aids, and may also be of interest to academics, graduate students, students and professionals interested in science and economic development of the region.
\end{abstract}

Keywords: Republic of Tatarstan, science, scientific institutions

\section{Introduction}

The questions of what regional science is, what its functions and objectives are, what structure and potential in Russian historiography it has have been studied for several decades. As early as in the 1970s, a number of researchers noted the fact that great attention was paid to studying history of formation of academic staff in the country, however, there was no research on the development of domestic science, history of establishment and improvement of the network of scientific institutions in the country (Komkov, 1977). It was noted that due to the increasing scale of modern scientific research, the rapid increase in the number of newly established research centres and institutions and large qualitative changes in their territorial distribution the study of the development of science all around the country acquired an important theoretical and practical significance (Belyaev, 1974).

Today the issue remains open. Science is developing and new forms of organization of scientific activity are appearing. Over the past twenty years the socio-economic and political situation in Russia has changed dramatically. In this context, significant changes have occurred in domestic science. The purpose of the research is to track these changes and reveal their direction.

It should be noted that regional study of the history of science in the Republic of Tatarstan in the 1920s-1980s was mainly represented by research on the history of the Communist Party. The situation changed marginally in the recent decade. However, from the new perspective of regional studies as a special branch of science, there has not been done any new research on the history of science and scientific-technical policy of the state in Tatarstan. The need for such kind of research has become essential. It should be noted that Russian researchers are actively developing this issue. Historiographical analysis has shown that poor coverage of the retrospective of development of science in the Republic of Tatarstan prevented from forming an integrated view on the ways and trends of its development in this large region of Russia. This research makes it possible to fill the gap. 


\section{Methodological Framework}

\subsection{Objectives of the Research}

The research put forward the following objectives:

1. To identify the system of factors causing the process of regionalization of science and stages of formation of regional science policy.

2. To identify major components of science policy in the Republic of Tatarstan.

3. To study the structure of regional scientific capacity in its organizational and personnel aspects.

4. To study the formation of mechanisms of regional coordination of science and systems of management of a complex of scientific institutions in the Republic of Tatarstan.

\subsection{Theoretical and Methodological Basis of Research}

The methodological basis of the research is a comprehensive approach based on the study of different types of sources. In addition, the research relied on the method of analysis of sources in order to identify and select sources and make a critical analysis of their content, and the method of system typological analysis which recreates the most complete picture of an event or phenomenon.

\subsection{Sources of Research}

The source base of the research are the published and unpublished archival documents stored in the National Archives of the Republic of Tatarstan and the current archives of the Tatarstan Academy of Sciences. The materials used in the preparation of the article can be divided into the following groups. The first group is the legislative and regulatory documents. The second group is administrative documents and records. The third group is narrative sources that were published and recorded by scholars, memories of some organizers of the Academy of Sciences in the republic. The fourth group consists of published materials on the history of cultural development of the region. Among the sources are the materials of all-Union and republican statistical compilations. Periodicals were also used as a valuable source of information on the development of the scientific potential of the republic.

\section{Results}

\subsection{Development of Science in Tatarstan in the $20^{\text {th }}$ Century}

The study showed that according to the level of development of academic, university and industrial science, the scientific personnel, and an extensive network of educational and research institutions Tatarstan held a leading position in the USSR. However, the republic, which had an autonomous status, was deprived of the right to establish its own Academy of Sciences.

The scientific potential of the republic increased significantly during the Great Patriotic War when Kazan hosted the institutions of the Academy of Sciences of the USSR evacuated from Moscow and Leningrad. Their fruitful research and scientific-organizational activity was the basis of opening of a branch of the Academy of Sciences of the USSR in the city of Kazan in 1945 that later became a major complex of academic science.

Thus, in the Soviet period in the republic on the basis of the available traditions of academic, university and industrial science and new major scientific schools there developed a considerable scientific potential. So, by the end of the 1980s, 14 higher educational institutions, 89 research institutes functioned in the republic.

However, the development of research activities in the republic lacked funding, the material base of the scientific institutions was weakened, and gradually science lost touch with practice and solution of the issues facing the republic. All this led to the crisis in science at the end of the 1980s. In this regard, there was an objective need to find new forms of organization and coordination of research activities in the republic.

Research has shown that implementation of science and technology policy in the 1990s generally contributed to the rise of inter-regional differences in Russian science that were related to the local economic and intellectual potential.

Analysis of the situation has shown that the scheme of management of science in the regions of Russia since the mid-1990s was not standardized and regulated. It did not take into account the existing scientific complex features of a region.

At the same time the Republic of Tatarstan developed its science policy. It was reflected in the establishment of the republican Academy of Sciences as a centre coordinating and prioritising the development of research activities (the Decree of the President of the TASSR of September 30, 1991 and 1991). There was an article in 
the republican budget on funding science.

Establishment of the Academy of Sciences in the republic contributed not only to the preservation of the existing scientific potential but also to the increase in the number of scientific institutions in the Republic of Tatarstan and the expansion of areas of research.

At the same time the unstable economic situation in Tatarstan and in the whole country under study did not allow the Government of Tatarstan to carry out adequate funding of science in the republic. This had a negative impact on the realization of research programmes that were important for Tatarstan. Later, an important economic lever for their implementation became a state Programme on Development of Priority Fields in the Republic of Tatarstan.

\subsection{Formation of Regional Scientific Complex in the Republic of Tatarstan in the 1990-2000s}

Scientific potential is inextricably linked to a particular socio-economic system which affects the process of formation and development of the scientific potential of the region, provides development of a material and technical base, training of researchers and their informational support.

In addition to the general prerequisites, regional science policy is influenced significantly by the internal logic and laws of science.

Thus, the research identified the main objective components that predetermine the establishment in a region of such a scientific institution as the Academy of Sciences: 1) a socio-economic factor (development of productive forces); 2) development of science (human resources).

When establishing the Academy of Sciences of the Republic of Tatarstan several concepts were discussed (Concept of Formation and Organization of the Tatarstan Academy of Sciences, 1991; Makhmutov, 1992). The research showed that the majority of scientists supported the view that the Academy of Sciences of the Republic of Tatarstan should become a union of academic interests with university and industry research. In our opinion, the union of academic institutions with specialized research centres significantly expanded the area of interests of the Academy of Sciences of the Republic of Tatarstan. Thus, the activity of the Academy of Sciences of the republic was beyond the classical academy. It was important for industry, agriculture, political, humanitarian and other issues of Tatarstan. It had a significant impact on the socio-economic development of the republic (Khasanov, 1994; Khasanov, 1995).

Over most of the $20^{\text {th }}$ century the republic paid much attention to the development of human scientific potential. So, if in 1922 there were 279 registered researchers, then, at the beginning of the 1990s, the scientific sphere of the republic had $2.3 \%(39,400$ people) of all the employed in the economy.

An important indicator of the general state of science in the Republic of Tatarstan is the number of doctors of sciences. The findings suggest that each year in the republic there was an increase in the number of doctors of sciences in all branches of science in general. The analysis shows that this growth was real and was caused mainly by the increase in the number of doctors of sciences in the already known scientific organizations.

The analysis shows that the Republic of Tatarstan has significant scientific potential. So, if by 1996 the number of doctors was about 746 people, then by 2000 their number was more than 1,500 (Science in the Republic of Tatarstan, 1997; Science in the Republic of Tatarstan, 2001).

In our opinion, the ethnic background of the scientific elite is of particular interest to the Republic of Tatarstan that has multi-ethnic composition of the population. The research shows that the doctors of sciences in Tatarstan are represented by about 20 nationalities. The largest ethnic groups are the Russians - $46 \%$ and the Tatars $38.2 \%$, the rest are united in the group "Others" $(15.8 \%)$. Thus, the ethnic component does not have any appreciable, independent, or self-sufficient role in training national highly qualified scientific personnel in the Republic of Tatarstan.

Despite the marked increase in the scientific personnel potential of the Republic of Tatarstan in the 1990s, training of highly qualified scientific personnel in the Republic of Tatarstan and in Russia remains an urgent issue. Therefore, the conclusion about the necessity of comprehensive measures for the rejuvenation of highly qualified personnel, in our opinion, is relevant.

\section{Discussions}

The study of the history of science in the Republic of Tatarstan can be divided into three periods: 1) 1920s mid-1950s; 2) mid-1950s - 1985; 3) 1985 - the present.

The first period is characterized by the appearance mainly of journalistic and scientific works dedicated to the 
establishment of the Soviet system of higher education and science (Science and Technology in the USSR, 1935; Vishnevski, 1921). These generally short in scope works represented the first attempt to take stock of a decade of scientific development of the republic in new circumstances and identify the main research areas. The essays contained information on all major aspects of the development of scientific potential of the republic: academic, university and industry sciences. During this period there were published essays devoted to an educational institution (mostly they were the works on the history of Kazan University, its departments, research schools, etc.), or some scientific directions. (Korbut, 1930; Bogoroditsky, 1952). A significant number of works from this period was devoted to the life and scientific work of scientists working in the national educational and research institutions (Abramov \& Aksenov, 1952).

Describing this period it should be noted that the ideological objectives of all the works emanated from the Marxist-Leninist ideology. They assessed the role of science too practically as a necessary tool to create the foundations of socialism. Many of them had a rather superficial approach that reflected only the external facts without analyzing the underlying processes or the causes of phenomena. There was no summarising research at all.

During the second stage there was a whole series of studies reflecting the history of certain universities of Tatarstan (Kazan Chemical and Technological Institute Named After S. Kirov, 1969; 50 ${ }^{\text {th }}$ Anniversary of Kazan Graduate Construction School, 1969; Kazan Agricultural Institute Named After M. Gorky, 1972; History of State Veterinary Institute Named After N. Bauman, 1973; Kazan University, 1973; Kazan Finance and Economics Institute Named After V. Kuibyshev, 1981). Extensive material of these works gives an idea of the main stages of development of the largest higher educational institutions of the republic as well as of the main directions of their scientific activity in the previous period. Historians of the republic also paid attention to the development of science in research institutes. However, no special research was carried out on the role and place of academic science in Tatarstan in the Soviet period.

At the same time, in some thematic collections there were published articles describing the status and prospects of development of various scientific fields (Arbuzov, 1971; Grigorian, 1978; Lebedev, 1978).

In 1960, in the anniversary book "Soviet Tatarstan is Forty Years Old" there was published a summarizing article "Higher Education and Science in Tatarstan over a 40-year period" containing many statistical and factual information $\left(40^{\text {th }}\right.$ Anniversary of Soviet Tataria, 1960). In 1975, in his research Valeev made a first attempt to summarize the history of the science of the Soviet Tatarstan from 1917 to 1970 (Valeev, 1975). In the essays he managed to reflect the main achievements of almost all important scientific directions for the republic engineering and chemical sciences, medicine, and social sciences. In 1986, the Institute of History, Language and Literature named after G. Ibragimov of Kazan Branch of the USSR Academy of Sciences published a paper "Cultural Revolution in Tatarstan (1917-1937)" which was the first work of this kind. The historians, on the basis of extensive archival material, were able to analyze the situation and identify regional characteristics of implementation of the policy of the Soviet state in the field of culture and science in Tatarstan.

There were a lot of works devoted to separate aspects of the activity of Kazan University, e.g. works by I. Ionenko \& V. Popov (1985), V. Aristov (1987).

Issues of realization of scientific and technical policy of the Communist Party in Tatarstan in the 1960s-1980s, improvement of forms and methods of integration of science and industry, strengthening of creative cooperation among scientists and industrial workers were studied by U. Belyalov (1978) and Yu. Voronin (1980). They mainly gave a conventional annotation analysis of scientific issues.

All of the works of the first and second periods contain a lot of factual material but as the society was highly ideological at the time, they are largely opportunistic in nature. In most cases, these works are narratives giving a list of scientific achievements and discoveries. However, there is no real analysis of the evolution of science in the republic, no analysis of the difficulties that science faced in the republic in the Soviet period. It should be also noted that the regional studies on the history of science in those years were mainly represented by the works, as a rule, on the history of the Party in which the state policy in the sphere of science was studied on the basis of adopted decrees and directives that were considered realised a priori when in fact their implementation required considerable effort and the results were not always consistent with the original plans. At the same time, they give a lot of useful and valuable factual material which, however, requires a comprehensive analysis from the point of view of modern methodology.

In the 1990 - 2000s the situation in historical science changed significantly. However, from the new perspective of regional studies as a special branch of science there were virtually no new works on the history of science and scientific-technical policy of the state. The methodological issue of development of science in the regions was 
not studied either. There were still published anniversary collections or articles that reflected the stages of development of certain universities or research institutes. For example, to celebrate the $200^{\text {th }}$ anniversary of Kazan State University there were published dozens of works devoted to some scientists working in universities and scientific schools (Perevedentsev, 2001; Busygin, 2002; Kazan Mathematical School, 2002; History of Kazan University, 2004 ). Similar publications marked the anniversary of the establishment of the Medical University of Kazan (Kazan Medical Institute, 1989), Kazan State Technological University (Kazan State Technological University, 2000), Kazan Technical University (Degtyarev, 2002), etc. There was published a number of articles in periodicals devoted to the anniversary of the establishment of the Kazan Scientific Centre of the Russian Academy of Sciences. To celebrate the $50^{\text {th }}$ anniversary of the Institute of Language, Literature and History of the Kazan Branch of the Academy of Sciences of the USSR, there were summed up the results of the development of social sciences in the republic (50 Years of Research and Discovery, 1989).

Modern researchers studying the history of science in the Republic of Tatarstan in the $20^{\text {th }}$ century are mainly interested in the period of the 1920s. This is especially true for the humanities as it was the sector which, in connection with the destruction of the old ideology, had to seek new ways of its development. Among the works devoted to this period there should be noted the research of G. Fattakhova and R. Valeyev (2002), A. Zaitsev (1998), E. Lebedeva (1998) and others.

Of particular interest to our study are the publications of the late 1980s - early 1990s which actively discussed the role of science in society. In the Republic of Tatarstan it acquired special significance in connection with the establishment of the Republican Academy of Sciences. However, there has not been carried out any integrated general research reflecting the development of science in the republic to the present day. Owing to the establishment in Tatarstan of the Academy there was a significant qualitative leap in its development dramatically that changed the status of science in the republic. Thus, the need for research of this kind has become essential.

Among Russian researchers the issue of history of science in the regions is being actively developed, especially in the recent decades (Yagovkin, 1995; Kupershtokh, 1995; Bazarova, 1998).

Historiographical analysis has shown that poor coverage of the retrospective of organization of science in the Republic of Tatarstan and lack of summarising research prevented from forming an integrated view of the ways and trends of the development of science in the region in the last decades. The issue remains open as to what extent these trends were consistent with the needs of scientific and technological progress, the way they were embodied in the system of regional science policy, the way the chosen path of development was implemented and to what extent it was effective.

\section{Conclusion}

The research conducted in accordance with the purpose and objectives allows us to make the following conclusions.

In the 1920-1930s, in the Tatar Republic on the background of intellectual and spiritual ascent there was a significant surge in scientific life. A lot of research institutes, universities, other research and educational institutions were established in the period. According to the level of academic, university and industrial science, human scientific potential, the presence of an extensive network of educational and research institutions, Tatar Republic held a leading position in the USSR, and Kazan was third after Moscow and Leningrad among university cities in the country. However, the republic, which had an autonomous status, unlike the Union republics, was deprived of the right to establish its own Academy of Sciences.

The scientific potential of the republic increased significantly during the Great Patriotic War, when Kazan hosted the evacuated Academy of Sciences of the USSR from Moscow and Leningrad. Their fruitful research and organizational work was the basis of opening of a branch of the Academy of Sciences of the USSR which consisted of five research institutes in the city of Kazan in 1945. In the post war decades, Kazan Branch of the Academy of Sciences of the USSR became a large complex of academic science widely known not only in the country but also abroad.

Analysis of academic science in the republic until late of the 1980s shows that during the Soviet period in the republic on the basis of the available traditions of academic science and established new major scientific schools there was formed considerable scientific potential. So, by the end of the 1980s the republic had 14 universities and 89 research institutes. However, despite the significant achievements in the field of science, the objective conditions for the further development of scientific schools and high scientific potential of the personnel, development of research activities in the country were accompanied by lack of funding which was connected 
with the economic policy of the USSR in autonomous entities.

Research shows that the implementation of science and technology policy in the 1990s in general contributed to the rise of inter-regional differences in Russian science related to the local economic and intellectual potential. Thus, in a number of subjects of the Russian Federation there were formed regional offices of science funded from regional budgets. Regions of Russia had different opportunities for scientific and technological development and, thus, there was inequality of starting opportunities of the subjects of the Russian Federation in the conditions of market economy. The study of state policy in the field of science in the Republic of Tatarstan of the last decade of the $20^{\text {th }}$ century showed that Tatarstan developed its policy on the development of science in the republic. First of all, it was reflected in the establishment of the Republican Academy of Sciences as a centre coordinating and prioritising the development of research activities. An article on funding science was introduced in the republican budget.

The republic managed to maintain the scientific potential, form a network of academic units with a developed material and technical base, and coordinate scientific resources to perform various research programmes for the benefit of the republic.

Over most of the $20^{\text {th }}$ century in Tatarstan much attention was paid to the development of human scientific potential. The findings suggest that each year in the republic there was an increase in the number of doctors of sciences in all branches of science in general. The growth was real and was caused mainly by the increase in the number of doctors of sciences in the already existing scientific organizations, i.e. universities, academic institutions of Kazan Scientific Centre of the Russian Academy of Sciences and the Academy of Sciences of the Republic of Tatarstan.

Nationality in the training of highly qualified scientific personnel in the Republic of Tatarstan does not play any appreciable, independent, or self-sufficient role. Such differences are not the result of specific state policy or intentional restraint of scientific interests of some nations over others.

Despite the marked increase in the scientific personnel in Tatarstan in the 1990 - 2000s, training of highly qualified scientific personnel in the republic and in Russia remains an urgent issue. Doctoral dissertations are mostly worked on at a more advanced age. Therefore, the conclusion about the necessity of comprehensive measures for the rejuvenation of highly qualified personnel, in our opinion, is rather relevant.

Thus, the establishment of the Academy of Sciences in the Republic of Tatarstan played a positive role. Despite the severe system crisis of science, sharp reduction in research institutions in the Russian Federation after the collapse of the Soviet Union, Tatarstan managed to keep under the auspices of the Republican Academy major scientific schools, the human scientific potential of the republic and provide a foundation for their development. Owing to stable funding and provision of the necessary material and technical base in the Academy of Sciences of the Republic of Tatarstan, there were created favourable conditions for scientific creativity and realization of fundamental and applied research in many important areas of science in Tatarstan.

\section{Recommendations}

The practical significance of the study are the findings and conclusions that can be used to define new organizational practices in the management of scientific and technical sphere, enhance the role of research in the conditions of political and economic reform of society and its transition to a market economy. The materials, concepts, summaries and recommendations of the research can be used in the further study of the issue of the development of scientific potential of Tatarstan and all Russia. The experience can be used in preparation of a large general work on the history of science in the region, development of training aids and specialized courses, and can also be of interest to academics, graduate students, students and anyone interested in the issues of science and economic development of the region.

\section{Acknowledgments}

This work was funded by the subsidy allocated to Kazan Federal University for the state assignment in the sphere of scientific activities.

\section{References}

$40^{\text {th }}$ Anniversary of Research, Teaching and Social Activities of an Honored Scientist, Doctor of Veterinary Sciences, Professor K. Bol (1896-1936). (1937). Scientific notes of Kazan Veterinary Institute, 47, 8-12.

50 years of Kazan Graduate Construction School (1919 - 1969). (1969). Kazan.

50 years of Research and Discovery. (1989). Kazan. 
Abramov, V., \& Aksenov, N. (1946). Boris Alexandrovich Arbuzov. Kazan.

Abutalipova, L. (Eds.). (2000). Crucial Decade. Kazan State Technological University (1991-2000): Historical Review. Kazan.

Andreev, I. (1996). History in Biographies: Kazan State Medical University. Faculty of Dentistry. Kazan.

Arbuzov, A. (1971). Kazan School of Chemists. Kazan.

Aristov, V. (1987). Pages of Glorious History: Stories about Kazan University. Kazan.

Barabanov, V. (Eds.). (2000). Kazan State Technological University. Professors, Doctors of Science. Polytechnic Institute - KCTU - KSTU (1919-2000): Brief Biographical Directory. Kazan.

Barabanov, V. (Eds.). (2000). Kazan State Technological University. Graduates - pride of Technological University. KCTU - KSTU (1931-2000): Brief Biographical Directory. Kazan.

Bazarova, G. (1998). Formation and development of scientific intelligentsia of Buryatia (1922-1985). Synopsis of Thesis of the Candidate of History. Ulan-Ude.

Belyaev, E. (1974). Issues of territorial distribution of science. Sociological problems of science. Moscow.

Belyalov, U. (1978). Communist Party's Rule of Socialist Industrialization in the Republics of the Middle Volga Region (1926-1940). Kazan.

Bogoroditsky, V. (1939). Kazan Linguistic School. Proceedings of the Moscow Institute of History, Philosophy and Literature. Kazan, 5, 265-297.

Busygin, E., \& Zorin, N. (2002). Ethnography at Kazan University. Kazan.

Decree of the President of TASSR of September 30, 1991. (1991). "On the establishment of the Academy of Sciences of the Republic of Tatarstan". Soviet Tataria. 2 October.

Degtyarev, G., \& Safariev, M. (2002). Kazan State Technical University named after A. Tupolev: People and Milestones. Kazan.

Essays on the History of Kazan University. (2002). Kazan.

Fattakhova, G., \& Valeev, R. (2002). Tatar Academic Center: 1920s. Kazan.

Grigoryan, N. (1978). Kazan Physiological School. Moscow.

History of Kazan University. (2004). Kazan.

History of the N. Bauman State Veterinary Institute. (1973). Kazan.

Ionenko, I., \& Popov, V. (1985). Kazan University in the Great Patriotic War. Kazan.

Izotov, G. (2003). Kazan Physics and Mathematics Society. Kazan.

Kamai, G. (1952). Academician A. Arbuzov. Kazan.

Kazan Agricultural Institute named after M. Gorky. (1972). Kazan.

Kazan Aviation Institute: Proc. (1982). Kazan.

Kazan Chemical-Technological Institute named after C. Kirov. 1919-1969. (1969). Kazan.

Kazan Finance and Economics Institute named after V. Kuibyshev. 1931-1981. (1981). Kazan.

Kazan Mathematical School, 1804-1954. (2002). Kazan.

Kazan Medical Institute (1814-1989). (1989). Kazan.

Kazan State Pedagogical Institute. (1974). Kazan.

Kazan State University named after V. Ulyanov-Lenin in 1917-1946. (1947). Kazan.

Kazan University. 1804-1979. (1979). Kazan.

Khasanov, M. (1994). In Two Years, We Have Been Recognized by More Than Ten Academies - Former Soviet Union and Abroad. Kazan Gazette, 23 February.

Khasanov, M. (1995). Annual General Meeting: results and objectives. Scientific Tatarstan, 2, 3-17.

Komkov, G., Levshin, B., \& Semenov, L. (1977). Academy of Sciences of the USSR. Moscow.

Korbut, M. (1930). Kazan State University named after V. Ulyanov-Lenin in 125-years-time. Scientific notes of Kazan University, 90(5), 778-812. 
Krasnov, P. (1931). Research work in Tatarstan over 10 years. Kazan.

Kupershtokh, N. (1995). Scientific Staff of the Siberian Branch of RAS: History of Formation and Development (1957-1970). Synopsis of the Thesis of the Candidate of History. Novosibirsk.

Lebedev, K., Volkov, I., \& Zefirov, L. (1978). From the History of Kazan School of Physiology. Kazan.

Lebedeva, E. (2002). Development of Science in the Volga Region in 1917 - first half of the 1920s. (On materials of Kazan, Saratov, Samara universities). Synopsis of the Thesis of the Candidate of History. Samara.

Makhmutov, M. (1992). Do we Need Our Own Academy? Soviet Tataria. January 21.

Mechanics and Mathematics Faculty of Kazan University: Historical Essays. (2003). Kazan.

Palkin, G. (1952). Essays on the History of Development of Animal Production Science in TASSR for over 30 years. Proceedings of the Kazan Branch of the Academy of Sciences of the USSR. Series of Biological and Agricultural Sciences, 3, 153-169.

Perevedentsev, Y. (2001). Meteorology at Kazan University: formation, development, major achievements. Kazan.

Poletaev, G., Sitko, L., \& Repina, D. (Eds.). (1994). Kazan State Medical University: 1814-1994. Departments of Kazan State Medical University. Kazan.

Science and Technology in the USSR. (1927). Moscow.

Science in Kazan University over the last two decades. (1930). Scientific notes of Kazan University, 3-4, 301-390.

Science in the Republic of Tatarstan. (1997). Statistical Yearbook of the State Committee on Statistics of the Republic of Tatarstan. Kazan.

Science in the Republic of Tatarstan. (2001). Statistical Yearbook of the State Committee on Statistics of the Republic of Tatarstan. Kazan.

Soviet Tatarstan is Forty Years Old. (1960). Kazan.

The concept of formation and organization of the Academy of Sciences of Tatarstan. (1991). Science, 6, 11-21.

Universities and Research Institutions. (1935). Moscow.

Valeev, M. (1975). To the Heights of Science. On the Development of Science in Tatarstan. Moscow.

Vekslin, N. (1930). Studying Tatarstan over a 10-year-period. Kazan.

Vishnievski, B. (1921). Organization of science in Tatar Republic. Journal of Education. Kazan, 1, 16-17.

Voronin, Yu. (1980). The Course of Scientific and Technical Progress. Kazan.

Yagovkin, V. (1995). Science in Siberia in 1965-1980. Synopsis of the Thesis of the Candidate of History. Irkutsk. 1995

Zaitsev, A. (1998). Historic Establishments of the Republic of Tatarstan of the 1920s-30s. Synopsis of the Thesis of the Candidate of History. Kazan.

Zefirov, A. \& Albitsky, V. (Eds.). (1997). Deans of Kazan Medical University: (From the Faculty of Medicine to Medical University) Biographical Dictionary of Deans of Kazan State Medical University. Kazan.

\section{Copyrights}

Copyright for this article is retained by the author(s), with first publication rights granted to the journal.

This is an open-access article distributed under the terms and conditions of the Creative Commons Attribution license (http://creativecommons.org/licenses/by/3.0/). 